\title{
Quality of Intellectual Capital and Human Resources Disclosure on the Firm Valuation
}

\author{
Abdolreza Ghasempour, Mohd Atef Md Yusof \\ Department of Accounting, Universiti Utara Malaysia, Sintok, Malaysia \\ Email: reza52 gh@yahoo.com
}

Received 20 December 2013; revised 25 January 2014; accepted 3 February 2014

Copyright (C) 2014 by authors and Scientific Research Publishing Inc.

This work is licensed under the Creative Commons Attribution International License (CC BY).

http://creativecommons.org/licenses/by/4.0/

(c) (i) Open Access

\begin{abstract}
Recent tendency of businesses towards voluntary disclosure has improved the quality of financial reporting. High-quality financial reporting helps users of financial information trust business, and thus, creates value for the business. The present study concerned itself with the voluntary reporting of intellectual capital and knowledge assets. Companies with large investments on knowledge assets, intellectual capital, and human resources, have managed to create great competitive advantage. The population of the present study was composed of 65 companies listed on Tehran Stock Exchange in the period from 2005 to 2012. The hypothesis testing results showed that voluntary disclosure of intellectual capital and human resources information had a significant and positive impact firm value, with a one year lapse. This is an indication of the importance of the disclosure of such information for financial statements users.
\end{abstract}

\section{Keywords}

Voluntary Disclosure, Intellectual Capital, Financial Reporting, Firm Value, Human Resources

\section{Introduction}

Today's movement towards knowledge economy has altered the governing paradigm of industrial economics, such that the advent of an economy based on knowledge and information is no longer considered farfetched. The foundation of such an economy is based on intellectual capital. Intellectual capital is defined as the collection of tangible and intangible resources, principles, culture, behavioral patterns, capabilities, qualities, structures, associations, procedures, and processes leading to or resulted by knowledge. Intellectual capitals and knowledge assets are being increasingly addressed by knowledge-based organizations to create sustainable competitive advantage.

Accountants in the 80s put sincere efforts into identification, measurement, and disclosure of intellectual capital of companies. Since the disclosure of information pertaining to intellectual capital is not mandatory, ac- 
counting is seeking to uncover factors influential on the voluntary disclosure of such information by companies, and also attempts to identify the fundamentals underlying different investor decision making under equal circumstances. Scholars, analyzers, and empiricists (including [1]-[3]) have concerned themselves with the incentives of companies for voluntary disclosure. Recent decades have observed numerous researchers trying to identify major variables defining the behavior of shareholders and other stakeholders. The present study is an attempt to further the mentioned studies.

Chtourou et al. [4] maintained that global investors and creditors base their decisions on the information reported in different economic, financial, and nonfinancial reports provided by stock exchange enlisted companies. Prior to decision-making concerning investment on a specific share, investors and creditors also take into account profitability, financial particulars, and nonfinancial particulars including staff information, Board Members' salary and benefits, and internal stock transfers. Therefore, voluntary disclosure, undertaken by many companies enlisted on world's most credible stock exchange markets, is a logical development of basic information disclosure in annual financial reports, necessarily reflecting the information pertaining to the economic realities of a company in a meaningful, transparent, and comparable manner [5]. In Iran, with the enactment of Internal Auditing By-Law as well as the By-Law of Corporate Governance the first steps have been taken towards voluntary disclosure on the part of companies. However, traditional and not so comprehensive and detailed disclosure of general information in the reports of Board of Directors or exclusive websites of companies, and very little in notes accompanying financial reports are still the only sources for optional and voluntary disclosure of information by Iranian companies.

Studies on voluntary disclosure have been conducted in many developed countries ([6]-[8]). In order for protecting the interests of public investors and the other parties in the market, a legal and efficient system of disclosure needs to be devised. With the development of securities market in many developed countries including the US (10-K Act) or East Asian countries such as China, a large amount of legal information concerning public disclosure of information has been published by the enlisted companies on Stock Exchange Markets for public consideration. Yet, scholars, analysts, and empiricists have regrettably not considered specific laws focusing on the incentives of firms for voluntary disclosure. Analytical studies indicate the fact that how competition influences disclosure levels ([1] [2], among many), and how disclosure is employed as a signal for firm's value (e.g. [3]). The present study is specifically concerned with the voluntary disclosure of information on intellectual capital and knowledge assets in Tehran Stock Exchange. This unique approach fills out some of the mentioned research gaps and further develops the related literature in a global level.

\section{Theoretical Framework and Review of the Related Literature}

Disclosure, in its simple and general sense, is defined as transferring and presenting economic information associated with the financial status and performance of firms, whether financial or nonfinancial, quantitative or in other forms. If it is made compulsory through sources of law, this disclosure is referred to as "mandatory disclosure", and if it is not mandated by any specific regulation, it is considered "voluntary disclosure". Furthermore, disclosure implies presenting a minimum amount of information in firm reports, based on which a reasonable evaluation of the firm's relative risks and value can be drawn and which can assist information users in this regard [7].

Both traditional (mainly monetary) and voluntary disclosure (mainly non-monetary) are efficient sources of information for stakeholders. Empirical studies on voluntary disclosure maintain a rather long history, commenced by Verrecchia [1], and followed by a plethora of complementary studies concerned with investigating the influence of other company features on disclosure, including size, type of stock exchange admission, leverage, and administrative structure (Table 1). Hughes [3] investigates the internet corporate reporting practices of

Table 1. Determining existence and type of causal relationship (Granger Causality Test).

\begin{tabular}{ccc}
\hline & F Statistic & Prob. \\
\hline Variable of firm value does not cause disclosure & 0.219 & 0.953 \\
Variable of disclosure does not cause firm value & 1.881 & $0.10^{*}$ \\
Number of observations & 128 & 128 \\
\hline
\end{tabular}


Greek listed companies. The aim is twofold: to contribute to the growing literature by examining internet corporate reporting for a small open European capital market; and to present a model of online dissemination of information by companies of all size in Greece. An Internet Disclosure Index (IDI) of 50 items is constructed, which incorporates content and presentation criteria. A total of 141 corporate websites were screened, and both partial and aggregates scores were produced. The scores show that the Greek companies have a lot of work to do in order to enhance the investor relations activities on the internet. On average, the larger, more established companies have significantly higher levels of disclosure for both financial and non-financial data.

Eng \& Mak [9] study the use of the Internet by Spanish companies to disclose financial information, we also discuss about the reasons of companies to use the new technologies to communicate with interested parties and its consequences. The empirical research is based on companies listed on the Madrid Stock Exchange, we analyze not only the information provided, but also the factors that explain the different attitudes of companies towards this vehicle for investors relationships. The results show that size is the main factor that explains not only the quantity but also the quality of financial information.

Expenses for development and collection of detailed information can be rather higher for small companies compared to large corporations. As, in large corporations, the mentioned information has already been developed for internal reporting to the administration, therefore, its disclosure shall not incur extra expenses ([7] [8]). Eng \& Mak [9] also maintain that production and dissemination of information is a costly activity and larger corporations probably have the required resources and expert staff for the dissemination of financial reports with high disclosure levels and consequently higher compliance with the disclosure regulations. It can thus be concluded that disclosure costs per unit are reduced and as a result large corporations disclose higher amounts of information. As quoted by Owusu-Ansah [7] and Stigler [10] considering the available economic facilities for information production and storage, large corporations are inclined to spend more resources for information production, and disclosure of information is higher in large corporations rather than small companies. OwusuAnsah [7] found out that the response to larger negative earnings is mostly obtained through voluntary disclosure by companies. Many studies today indicate the effects of disclosure on the cost of capital (Botosan [11]) and the cost of debt (Sengupta [12]). There are also numerous studies on corporate governance and disclosure ([4] [6] [7] [9] [13] [14]). In Iran, it seems, there are significant research gaps in this area. Little research has been conducted on the subject under discussion in Iran, with each one addressing only small portions of voluntary disclosure literature ([15]-[18]). Taking into account different stakeholder groups, the present study has attempted to further develop the literature in many aspects nationally and in a few aspects worldwide.

Francis [19] had three objectives: 1) identify design attributes for Web-based financial reporting; 2) rank those attributes; and 3) pilot test the Web as a survey tool. Sixty-one attributes were developed from prior studies. The subjects were the subscribers of the "Double Entries" email newsletter. In terms of completeness, the respondents suggested seven additional attributes. Regarding the second objective, some surprises were found. In terms of presentation, the respondents were moderately adverse to downloading files, gave relatively low ratings to "bells and whistles," preferred hyperlinks and other navigation aids such as tables of content over search and query functions. Regarding the third objective, the response rate was $13.2 \%$, which was at the low end of response rates reported by similar projects.

O'Dwyer ([8] [20]) investigated first-hand the incentives of directors for social information disclosure in annual reports. The results showed that directors maintain that social pressures necessitate the accountability of companies and disclosure of information in annual reports is deemed as a gesture of redeeming their legitimacy.

Another study by Klein [6] investigated the influence of governance, corporate governance mechanisms, and firm-specific characteristics on the voluntary disclosure of Shanghai Stock Exchange listed companies. The results indicated that sole proprietorship, existence of an audit committee, firm size, and leverage are significantly related to voluntary disclosure. Their findings moreover indicated an understanding of disclosure behavior in state-owned entities during the privatization process in China. This study intends to investigate different governance variables and firm-specific characteristics within the framework of Stakeholder Theory.

Klein [6] focused on the integrity of Internet Financial Reporting (IFR) by reference to the adequacy of underlying corporate governance procedures. Using a sample of 100 large European companies, a questionnaire survey was used to identify whether or not governance procedures that specifically address the distinguishing features of web-based financial reporting are used by large companies. The results confirm the trend identified in prior research of increasing Internet usage to replicate paper-based financial information. Responses to the questionnaire also suggest that concerns about the integrity of IFR are justified. Erroneous assumptions and as- 
sertions by respondents regarding the security of IFR, in addition to knowledge of work undertaken by external auditors indicate limited engagement with IFR by management of large European companies.

In Australia, Hughes [13] utilized Legitimacy Theory to explain the changes in disclosure of environmental reports by enterprises for periods in which authorities, including the government and Environmental Protection Organization, emphasized compliance with environmental protection regulations. The results portrayed that during the years companies were pressured to comply with environmental protection regulations, their disclosure tended to be more desirable and comprehensive in this regard, as compared to the other years. They also found out that regulatory requirements concerning environmental protection coerces enterprises to turn to environmental disclosure. It seems that business entities struggle to retain their legitimacy via voluntary disclosure when they have violated a social contract.

Deegan et al. [3] conducted a study on the methods of social and environmental disclosure employed by Australian companies. The results supported the legitimacy-seeking incentives of directors of socio-environmental information-disclosing companies. In another study, Kashanipoor et al. [16] investigated the relationship between voluntary disclosure of a company and the number of its non-executive directors. Their sample was composed of 239 companies. Their disclosure checklist listed 71 items. Their results showed that there was not a significant relationship between voluntary disclosure and the percentage of non-executive directors on the Board.

Sajadi et al. [18] studied the relationship between five nonfinancial characteristics of Tehran Stock Exchange listed companies and the quality of their financial reporting. To measure the financial reporting quality, an index was employed containing 155 items, following Iran Accounting Standards and other disclosure pertaining regulations, to investigate possible relationships between the firm size, type of auditing institute, type of industry, ownership structure, and company age, and financial reporting quality, using models of multiple regression. The results showed that firm size, company age, and type of industry maintained significant positive relationships while ownership structure had a negative relationship with the financial reporting quality, whereas the relationship between type of auditing institute and financial reporting quality was not significant.

In their applied descriptive-survey study, Karbasi Yazdi, Hemati, and Bayat [21] investigated the feasibility of social reporting by Tehran Stock Exchange listed companies, collecting the data using questionnaires. They concluded that social reporting is not well-received for a couple of reasons, namely: absence of a proper accounting information system, reluctance of directors to disclose company's social costs, absence of legal standards, and high costs of developing social reports. They also provided evidences indicating that directors are more inclined to disseminate measures they have taken concerning employee welfare and health, charity, and environmental protection. These research summarized in followed table:

\begin{tabular}{|c|c|c|c|}
\hline Casabona & 2005 & London & $\begin{array}{l}\text { Maintained that global investors and creditors base their decisions on } \\
\text { the information reported in different economic, financial, and } \\
\text { nonfinancial reports provided by stock exchange enlisted companies. }\end{array}$ \\
\hline $\begin{array}{l}\text { Owusu-Ansah and } \\
\text { Stigler and Alchin }\end{array}$ & 1969 & Hong Kong & $\begin{array}{l}\text { Considering the available economic facilities for information production } \\
\text { and storage, large corporations are inclined to spend more resources } \\
\text { for information production, and disclosure of information is higher } \\
\text { in large corporations rather than small companies. }\end{array}$ \\
\hline Skinner & 1994 & Seol & $\begin{array}{l}\text { found out that the response to larger negative earnings is mostly } \\
\text { obtained through voluntary disclosure by companies }\end{array}$ \\
\hline $\begin{array}{l}\text { Karbasi Yazdi } \\
\text { and Bayat }\end{array}$ & 2012 & $\begin{array}{l}\text { Tehran Stock } \\
\text { Exchange }\end{array}$ & $\begin{array}{l}\text { They concluded that social reporting is not well-received for a couple of reasons, } \\
\text { namely: absence of a proper accounting information system, reluctance of directors } \\
\text { to disclose company's social costs, absence of legal standards, and high costs of } \\
\text { developing social reports. They also provided evidences indicating that directors } \\
\text { are more inclined to disseminate measures they have taken concerning employee } \\
\text { welfare and health, charity, and environmental protection. }\end{array}$ \\
\hline O’Dwyer & 2002 & Stoklohm & $\begin{array}{l}\text { Investigated first-hand the incentives of directors for social information disclosure } \\
\text { in annual reports. The results showed that directors maintain that social pressures } \\
\text { necessitate the accountability of companies and disclosure of information in } \\
\text { annual reports is deemed as a gesture of redeeming their legitimacy. }\end{array}$ \\
\hline Dismand and Yan & 2009 & $\begin{array}{l}\text { Shanghai Stock } \\
\text { Exchange }\end{array}$ & $\begin{array}{l}\text { Their findings moreover indicated an understanding of disclosure behavior in } \\
\text { state-owned entities during the privatization process in China. This study } \\
\text { intends to investigate different governance variables and firm-specific } \\
\text { characteristics within the framework of Stakeholder Theory. }\end{array}$ \\
\hline
\end{tabular}




\section{Continued}

\begin{tabular}{|c|c|c|c|}
\hline Sengupta & 1998 & Australia & $\begin{array}{l}\text { The results portrayed that during the years companies were pressured to comply } \\
\text { with environmental protection regulations, their disclosure tended to be more } \\
\text { desirable and comprehensive in this regard, as compared to the other years. } \\
\text { They also found out that regulatory requirements concerning environmental } \\
\text { protection coerces enterprises to turn to environmental disclosure. }\end{array}$ \\
\hline Deegan et al. & 2002 & $\begin{array}{l}\text { Australian } \\
\text { companies }\end{array}$ & $\begin{array}{l}\text { The results supported the legitimacy-seeking incentives of directors } \\
\text { of socio-environmental information-disclosing companies. }\end{array}$ \\
\hline $\begin{array}{l}\text { Kashanipoor, Rahmani, } \\
\text { and Parchini Parchin }\end{array}$ & 2009 & $\begin{array}{l}\text { Tehran Stock } \\
\text { Exchange }\end{array}$ & $\begin{array}{l}\text { Their results showed that there was not a significant relationship between } \\
\text { voluntary disclosure and the percentage of non-executive directors on the Board. }\end{array}$ \\
\hline Sajadi et al. & 2009 & $\begin{array}{l}\text { Tehran Stock } \\
\text { Exchange }\end{array}$ & $\begin{array}{l}\text { The results showed that firm size, company age, and type of industry maintained } \\
\text { significant positive relationships while ownership structure had a negative } \\
\text { relationship with the financial reporting quality, whereas the relationship between } \\
\text { type of auditing institute and financial reporting quality was not significant. }\end{array}$ \\
\hline
\end{tabular}

\section{Voluntary Disclosure, Agency Theory and Research Hypothesis}

Agency theory attempts to explain why manager decide to disclosure voluntary information in annual reports ([22]-[24]). The theory was first derived from the dilemma of separated ownership and control ([25]) and later refined by Jensen and Mechling [23]. Information asymmetry is central in agency theory, were managers possess more information than shareholders. Watts and Zimmerman [22] argue that management make decisions based upon self interest. The scholars ([22]) further claim that management (the agent) is aware of the information asymmetry and the control mechanism, contracts and monitoring, which shareholders (The principal) impose upon them. Providing additional information may reduce the firm agency costs, expenditure on monitoring and contracting, and earn shareholders' trust [26].

Jensen \& Meckling [23]) in the agency theory provides a framework linking disclosure behavior to corporate governance. Corporate governance mechanisms are introduced to control the agency problem and ensure that managers act in the interests of shareholders. Theoretically, the impact of internal governance mechanisms on corporate disclosures may be complementary or substitutive. If it is complementary, agency theory predicts that a greater extent of disclosures is expected since the adoption of more governance mechanisms will strengthen the internal control of companies.

Further, agency theory provides a framework for analyzing financial reporting incentive between managers and owners. Signaling theory explains why firms have an incentive to report voluntarily to the capital market even if there were no mandatory reporting requirements, and voluntary disclosure is necessary in order to come successfully in the market for risk capital, the ability of the firm to raise capital will be improved if the firm has a good reputation with respect to financial reporting. Positive agency theory ([23] [27] [28]) provides a framework for linking corporate governance to voluntary disclosure. According to agency theory a company with high agency costs will try to reduce them by increasing the extent of voluntary disclosure and employing "intensive" monitoring devices, like the presence of outside directors on a corporation's board. Voluntary disclosure is a function of the governance structure of the firm and managers' attitudes to voluntary disclosure changes accordingly to the trade-off of the costs and benefits involved.

Theoretical and empirical studies on voluntary disclosure benefits have been shown that voluntary disclosure: decreases the cost of capital [e.g., [29]-[32]] by raising the price of stock relative to the share price of firms not disclosing that information, reduce the information asymmetries between informed and uniformed investors and hence improves the firm's stock liquidity [e.g., [3] [5] [33]-[35]] and generally affects shareholders' wealth [36] [37].

Disclosure is not costless, as it is associated with the emergence of proprietary and litigation costs [[8] [38] [39]]. The cost of disclosure is the threat to competitive advantage caused by providing proprietary information to competitors.

Because disclosure is selective, managers exercise discretion in the disclosure of information. Previous theoretical models of voluntary disclosure [3] predicts that, in the presence of disclosure-related costs, firms will disclose only when their performance level exceeds a certain threshold, while below the threshold will not. In the presence of rational trader expectations, managers exercise discretion "choosing the point (the threshold level of disclosure) above which he disclosed what he observes, and below which he withholds his information" (idem, p. 179). The reason behind this is that managers will attend to signal what they know to achieve econom- 
ic benefits [see, [40] [41]]. Although, due to litigation concerns, Skinner (1997) document that managers provide a more timely disclosure of adverse earnings news in order to lower the expected legal costs. In the same vein, Lev [28] assert that managers voluntary disclosed adverse earnings news "early", before the mandated release date, to reduce stockholder litigation costs.

Moreover, voluntary disclosure is positively associated with firm size ([42] [43]), with the number of analysts following a firm [42] as well as the listing status and earnings margin [44]. Lightstone [45], show that financial leverage, proportion of assets-in place is associated with voluntary disclosure choices. Weisbach [26] has introduced the theoretical framework relating disclosure quality to corporate governance. Based on that, in the last decade a series of empirical researchers has studied how different corporate mechanisms impact on the extent of voluntary disclosure [9] [26] [32] [46].

Eng and Mak (2003) conducted a study on 158 companies listed on Singapore Stock Exchange and they found that board composition, measured by the proportion of outside directors have a negative impact on the amount of corporate voluntary disclosure. Gray [47] documented a negative relationship between expert outside directors and the level of voluntary information. In the same vein, Chau [48] in a study on UK companies, focusing on corporate governance mechanisms, such as the presence of non-executive directors and audit committee document that both mechanisms does not influence the disclosure of share-option compensation in the annual reports. Catasús [49] using a weighted relative disclosure index in measuring voluntary disclosure in the Hong Kong context, found that family-controlled firms have a negative impact on the extent of voluntary disclosure.

The empirical evidence on these studies shows mixed and controversial results. These may be due to specific institutional settings (Hong Kong, Singapore, UE, US, etc.) and/or firm-specific characteristics, the different institutional environments across countries, outside investor rights and legal enforcement ([34] [43]), the measurement of corporate governance and voluntary disclosure variables ([8] [40]) or different research contexts play a key role in determining the level of voluntary disclosure. Ahmed and Courtis (1999, p.36) argued that "these inconclusive results could be due to differences in socio economic and political environments between countries.”

Previous research on governance and voluntary disclosure mainly focused on the agency theory perspective, however results are unable to confirm if corporate governance and voluntary disclosure acts as complementary or substitute mechanisms of control. Corporate governance and voluntary disclosure can be seen as complementary mechanisms, when internal decision making mechanisms, as board of director strengthen the extent of voluntary disclosure. Instead, if the relationship is substitutive, one corporate governance mechanism may substitute for another one, and companies will choose to improve one at the expense of the other one [50]. For example, if a company chooses a monitoring mechanism, like the presence of an outside director on a firm's board this may indicate that the firm is being closely monitored already and there is a lower probability that the firm will increases its disclosure level. Also, if information asymmetry in a firm can be reduced as a consequence of "internal monitoring packages", the need of having additional governance devices is smaller.

While previous papers ([12] [19] [40]) concentrated mainly on the well known agency theory classification into independent and executive directors, following [18] [36] typology of board members and ulterior empirically studied by Graham [40], we classify independent directors into four categories, as following: business experts, community influential, support specialists and insiders.

So, after discussed above we determined followed Research Primary Hypothesis:

There is a significant and positive relationship between the voluntary disclosure of intellectual capital and human resources information and company's market value.

\section{Methodology}

This is a descriptive-library study in terms of data collection, an applied study in terms of the objective, and concerning hypothesis testing, this study is classified as correlational, adopting a deductive-inductive approach, and of causal-comparative type. In terms of sampling method it is a semiempirical study. Initially, the population was studied, including Tehran Stock Exchange listed companies which have been active from March 2005 through to 2012. Of course, for mean calculation for some of the variables, the period was extended to include March 2002. Then, the companies lacking the required characteristics were excluded, and the sample was ultimately selected from among the remaining companies. The designated variables were later on extracted from 
different information sources, databases, and financial reports of the sample companies, and consequently the hypotheses were tested.

\subsection{Sample and Sampling Procedure}

The population of the present study was Tehran Stock Exchange listed companies which have been active from March 2005 through to 2012. Approximately 330 companies have been active on Tehran Stock Exchange since March 2002. However, for mean calculation of some variables, the period has been extended to include March 2002, adding up to a number of 320 active companies. Tehran Stock Exchange Organization was the research location. Research period is from March 2002 to March 2012. As for hypothesis testing, the companies were selected as sample only if:

1) The company is not in the financial intermediation industry, as the capital structure of these institutes are different;

2) The company has been enlisted on Tehran Stock Exchange since March 2002;

3) The company's ticker symbol does not suffer a significant halt (i.e. does not suffer a halt of more than 3 months on the stock market board);

4) The company's data are available;

Having considered the above-gone conditions, the population shrank to 182 companies, out of which 65 companies were randomly selected and analyzed as the sample. The pertinent data was investigated for a 7-year period, i.e. a total of 455 observations (year-company) were tested for hypothesis testing.

$$
n \geq \frac{N Z_{\alpha / 2}^{2} \times P(1-P)}{(N-1) \epsilon^{2}+Z_{\frac{\alpha}{2}}^{2} \times P(1-P)}=65
$$

\subsection{Research Variables}

Research variables are listed below as employed in the first section:

Voluntary Disclosure Index (VolDiscT): (Francis, Nadia and Olson, [19], Ali Bayat, [15]): Voluntary disclosure is defined as disclosure of information by companies besides what mandated by Iranian Accounting Standards, including the entire financial and nonfinancial items, not enlisted on the Adequacy of Disclosure Checklist.

Different studies in the pertinent literature, have adopted various criteria and scores for measuring voluntary disclosure: management forecasts, managerial speeches, self-constructed scores, and standard scores constructed by credible rating agencies (Association for Investment Management and Research (AIMR) Scores and Standard \& Poor's (S\&P) Transparency and Disclosure Scores, for instance), to mention a few. The self-constructed score was selected for measuring voluntary disclosure for two reasons: first, Healy and Palepu [51] have stated that self-constructed scores are more trustworthy, and properly measure what they stand for (validity). Self-constructed rating scores are more successful than standard disclosure indices especially in cases where many questions are raised concerning the efficiency of externally designed measuring indices (e.g. whether this rating procedure is capable of properly measuring the changes in disclosure approaches taken by the company?). To extract voluntary disclosure index, this study employed a weighted disclosure index for measuring the disclosure score of each and every company; a disclosure index was developed to meet this end, composed of approximately 42 items pertaining to human resources and intellectual capital [15].

Every individual item was assigned with a unique score, depending on the perceived importance, and weight and extent of disclosure by the company. These scores were mostly retrieved from the company's website and Board reports. Voluntary disclosure index can therefore be defined as:

$$
\operatorname{VolDisc}_{j}=\frac{1}{n_{j}} \sum_{i=1}^{n_{j}} w_{i} d_{i}
$$

In which:

VolDisc $_{j}$ is the disclosure weight index for the company $j$, and $w_{i}$ represents the assigned weight to the informational item $i$, as disclosed by the company $j$.

Abnormal Earnings (AbE): deviation of the company's earnings from the average earnings over the past 5 
years;

Firm Size (SIZE): natural logarithm of the company's total average stock market value;

Firm Value: Different methods can be adopted for evaluating a firm's value, including but not limited to: dividend discount model, discounted cash flow model, economic profit model, and accounting profit model. Firm value is composed of two components of shareholder value (capital value) and value of the creditors (creditor value). As for the present study, Tobin's $Q$ is employed as a criterion for firm value. Depending on the research requirements, different researchers have adjusted Tobin's $Q$ calculation. Kelin [6] and Badaver [51], for instance, have calculated the said criterion as: the ratio of average market value of assets to average book value of assets.

Deegan [3] have proposed Tobin's $Q$ as an index for evaluating companies. Previous studies show that Tobin's $Q$ in companies with measurable intangible assets (besides physical capital assets), including a good management team and proper governance structure. Badaver [51] maintains that $Q$ may also be considered as an index for growth opportunities. He utilized the formula proposed by Perfect and Deegan [3] to calculate Tobin's $Q$, which we will also use for the present study. Their proposed index follows:

$$
Q=\frac{M V(\text { Eqity })+B V(\text { Debt })}{B V(\text { Asset })}
$$

The ultimate proposed models for investigating the impact of firm value on voluntary disclosure were extracted as follows:

$$
\text { Fvalue } T=\alpha_{0}+\alpha_{1} B V+\alpha_{2} A b n E+\alpha_{3} \text { Size }+\alpha_{4} \text { VolDisc }+\psi
$$

Furthermore, as for the experimental test of the impact of disclosure on firm value, the authors will adopt the revised Ohlson's model of evaluation of companies (1995), in which firm value equals book value of capital and abnormal earnings.

\section{Research Findings}

\subsection{Pretest-Investigating the Causal Relationship between the Voluntary Disclosure Variable and Firm Value in the Model (Granger Causality Test)}

Prior to commencing model estimation, it must first be investigated whether the mentioned variables maintain reciprocal causation, theoretically speaking; which one causes the other; and whether there is a causal relationship between them. Granger causality test was utilized to meet this end, the results of which are given in Table 1.

Results from Granger causality test reveal that voluntary disclosure of intellectual capital causes firm value at a confidence level of $90 \%$.

\subsection{Step One: Panel or Mixed Model Identification (F-Limer Test)}

Prior to model estimation, it needs to be identified that whether the model is with single or multiple y-intercepts, i.e. whether there is a panel or mixed distribution. F-Limer test was utilized to meet this end. Results of the mentioned tests for models pertaining to the first theory are presented in Table 2.

Table 2. Panel or mixed model identification (F-Limer Test).

\begin{tabular}{ccc}
\hline Model & F-Statistic & $\chi^{2}$ Statistics \\
\hline F-Statistics & 1.616 & 108.990 \\
Prob $>$ F & 0.004 & - \\
Prob $>\chi^{2}$ & & 0.0000 \\
Number of observations & 388 & 388 \\
Model Type & Mixed & Mixed \\
\hline
\end{tabular}


Here, the $\mathrm{H}_{0}$ hypothesizes non-panel distribution. As shown by the results, the $\mathrm{H}_{0}$ can be rejected. As stated above, panel data has a single y-intercept, while mixed data has multiple y-intercepts.

\subsection{Step Two: Random Effects Test and Hausman Test}

Having determined the type of y-intercept, the next issue to deal with is whether the discussed y-intercepts are fixed or random. From a theoretical point of view, if all the y-intercepts of the population are present, the model will be fixed effect model. It, however, should be kept in mind that in case the conditions justify random effect estimation theory, a Hausman Test needs to be conducted primarily, and if that rejects, fixed effect model is the correct procedure. The $\mathrm{H}_{0}$ of Hausman test proved that the model is a random effects model. The important point to be considered here is that the basis of Hausman test is that the test is required to be estimated randomly first, only then can the Hausman test be conducted. Results from the above tests for the first model are presented in Table 3.

According to the results, the model needs to be estimated as fixed effects of the y-intercepts.

\subsection{Step Three: Heteroscedasticity Test}

One of the problems of the regression model is the Heteroscedasticity of modeling errors, caused by the violation of the hypothesis $\operatorname{Var}\left(U_{i}\right)=\sigma^{2} I$. Such an issue in the regression will cause the OLS results to be no longer efficient. The $\mathrm{H}_{0}$ here is Homoscedasticity.

Generalized least squares were adopted for cases of approved Heteroscedasticity.

\subsection{Step Four: Autocorrelation Test}

Another recurrent problem in a regression model is autocorrelation between the residuals. Autocorrelation is violation of one of the standard assumptions of the regression model (the assumption: $\operatorname{COV}\left(\mathrm{u}_{\mathrm{i}}, \mathrm{u}_{\mathrm{j}}\right)=0$ ). The OLS estimation technique, thus, loses the best linear unbiased estimator (BLE) feature, and as a result, the statistical inference would render unreliable. The autocorrelation problem can exist as first order autoregressive process (AR(1)), higher orders, or moving average process (MA(q)). The $\mathrm{H}_{0}$ here is the absence of autocorrelation. In cases observed with first order autocorrelation, coefficient estimates such as AR(1) were used to obviate autocorrelation.

\subsection{Step Five: Final Estimate of Regressive Models}

The final model is consequently estimated in the final step subsequent to diagnostics. Results of model estimates are given in Table 4.

As shown by the results in Table 4, the t-statistics for variables of size and voluntary disclosure of intellectual capital information have significant and positive relationship with firm value at the significance level of 0.05 . The mentioned statistics for the same variables is 2.471 and 2.216 in the main model, respectively. In other words, the results show that larger corporations and companies with higher voluntary disclosure levels of intellectual capital and knowledge assets information are considered more valuable by the investors, and investors are probably ready to pay larger sums of money for stocks of such companies. Another reason to this may be that such companies have to follow certain requirements to promote the quality of their human resources to be

Table 3. Random effects and Hausman tests for the model.

\begin{tabular}{cccc}
\hline Model & Fixed & Random & Prob. \\
\hline Book Value & 0.000 & 0.000 & 0.928 \\
Abnormal Earnings & 0.000 & 0.000 & 0.414 \\
Size & 0.132 & 0.188 & 0.004 \\
Voluntary Disclosure & 0.005 & 0.003 & 0.092 \\
Final Result & $\chi^{2}$ Statistics & Prob $>\mathrm{chi}^{2}$ & Final Result \\
\hline
\end{tabular}


Table 4. Final estimate of the regressive model.

\begin{tabular}{ccccc}
\hline Variables & Coefficients & Standard Deviation & t-Statistics & Level of Significance \\
\hline y-Intercept (C) & -0.404 & 0.698 & -0.579 & 0.563 \\
Beginning Book Value BV (-1) & 0.000 & 0.000 & 0.212 & 0.831 \\
Abnormal Earnings (AE) & 0.000 & 0.000 & 0.953 & 0.341 \\
Size & 0.132 & 0.053 & 2.471 & $0.014^{* *}$ \\
Last Year Intellectual Disclosure D (-1) & 0.005 & 0.005 & 2.216 & $0.027^{* *}$ \\
& Adj._R $\mathrm{R}^{2}$ & $\mathrm{~F}$ & Prob. > chi $^{2}$ & Obs. \\
& 0.129 & 1.850 & 0.000 & 388 \\
\hline
\end{tabular}

${ }^{* * *},{ }^{* *}$, and ${ }^{*}$ indicate significant at $1 \%, 5 \%$, and $10 \%$ respectively.

able to obtain certifications including Occupational Health and Safety Act (OHASA18000), Integrated Management System (IMS), International Organization of Standardization (ISO15000), European Foundation for Quality Management (EFQM); thus, they tend to disclose such information in an attempt to inform their stakeholders of the company's commitment towards these standards; by estimating the positive perspective for these companies and the probable access to future growth opportunities, investors are willing to allocate more resources to purchase their stocks.

\section{Discussion and Conclusions and Proposals}

The present study investigated voluntary disclosure of intellectual capital, human resources, and knowledge assets by Tehran Stock Market listed companies as well as their impact on the evaluation of such companies by investors. Results of hypothesis testing indicated that variables of size and voluntary disclosure of intellectual capital information have significant and positive relationship with firm value at the significance level of 0.05 . Based on the results, larger corporations and companies with higher voluntary disclosure levels of intellectual capital and knowledge assets information are considered more valuable by the investors, and investors are probably ready to pay larger sums of money for stocks of such companies. Another reason to this may be that such companies have to follow certain requirements to promote the quality of their human resources to be able to obtain certifications including Occupational Health and Safety Act (OHASA18000), Integrated Management System (IMS), International Organization of Standardization (ISO15000), European Foundation for Quality Management (EFQM), thus, they tend to disclose such information in an attempt to inform their stakeholders of the company's commitment towards these standards; by estimating the positive outlook for these companies and the probable access to future growth opportunities, investors are willing to allocate more resources to purchase their stocks.

As for the majority of variables, findings of the present study are consistent with similar studies conducted in other countries ([2] [3] [5] [8] [12] [14] [19] [20]).

The results of the present study suggest that in their investment decisions, analyzers should take into account voluntary disclosure. It is also suggested that Tehran Stock Market devises incentives for smaller companies to further encourage voluntary disclosure. The results of this paper can be used by corporations, investors, analysts, standard makers, and researchers. Also, investors can be investing in the companies they consider to voluntary information. Tehran listed companies must be more interested to voluntarily self-disclose information. Indeed, Tehran Exchange organization must encourage companies to take voluntary online reporting; further more researchers could have paid more attention to other aspects of intellectual capital information disclosure and study various aspects of their development.

\section{References}

[1] Verrecchia, R. (1983) Discretionary Disclosure. Journal of Accounting \& Economics, 5, 179-194. http://dx.doi.org/10.1016/0165-4101(83)90011-3

[2] Deegan, C., Rankin, M. and Tobin, J. (2002) An Examination of the Corporate Social and Environmental Disclosures 
of BHP from 1983-1997: A Test of Legitimacy Theory. Accounting, Auditing \& Accountability Journal, 15, 312-343. http://dx.doi.org/10.1108/09513570210435861

[3] Hughes, K.E. (2000) The Value Relevance of Nonfinancial Measures of Air Pollution in the Electric Utility Industry. The Accounting Review, 209-228. http://dx.doi.org/10.2308/accr.2000.75.2.209

[4] Chtourou, S.M., Bedard, J. and Courteau, L. (2001) Corporate Governance and Earnings Management. Working Paper, Universite Laval, Canada.

[5] Verrecchia, R. (2001) Essays on Disclosure. Journal of Accounting and Economics, 32, 97-180. http://dx.doi.org/10.1016/S0165-4101(01)00025-8

[6] Klein, A. (2002) Audit Committee, Board of Director Characteristics, and Earnings Management. Journal of Accounting and Economics, 33, 375-400. http://dx.doi.org/10.1016/S0165-4101(02)00059-9

[7] Peasnell, K.V., Pope, P.F. and Young, S.E. (2001) The Characteristics of Firms Subject to Adverse Rulings by the Financial Reporting Review Panel. Accounting and Business Research, 31, 291-311. http://dx.doi.org/10.1080/00014788.2001.9729621

[8] O’Dwyer, B. (2001) Managerial Perceptions of Corporate Social Disclosure: An Irish Story. Accounting, Auditing and Accountability Journal, 15, 406-436. http://dx.doi.org/10.1108/09513570210435898

[9] Eng, L.L. and Mak, Y.T. (2003) Corporate Governance and Voluntary Disclosure. Journal of Accounting and Public Policy, 22, 325-345. http://dx.doi.org/10.1016/S0278-4254(03)00037-1

[10] Stigler, G.J. (1964) A Theory of Oligopoly. Journal of Political Economy, 72, 44-61. http://dx.doi.org/10.1086/258853

[11] Botosan, C. (1997) Disclosure Level and the Cost of Equity Capital. The Accounting Review.

[12] Sengupta, P. (1998) Corporate Disclosure Quality and the Cost of Debt, The Accounting Review, 73, 459-474.

[13] Xie, B., Davidson, W.N. and Da Dalt, P.J. (2001) Earnings Management and Corporate Governance: The Roles of the Board and the Audit Committee. Working Paper, Southern Illinois University, Carbondale.

[14] Beekes, W., Pope, P. and Young, S. (2002) The Link between Earnings Conservatism and Board Composition: Evidence from the UK. Working Paper, Lancaster University, Lancaster.

[15] Bayat, A. (2012) The Relationship between the Levels of Voluntary Disclosure, the Cognitive Styles of DecisionMaking, and Information Asymmetry: According to Stakeholder Theory. Ph.D. Dissertation in Accounting, Islamic Azad University.

[16] Sajadi, H., Zeranejad, M. and Jafari, A. (2009) Nonfinancial Characteristics Effective on Financial Disclosure Quality in Tehran Exchange Market Listed Companies. Accounting and Auditing Assessments Journal, 16, 51-68.

[17] Foroughi, D., Shahshani, M.M. and Poorhossein, S. (2008) Directors' Attitude towards Disclosure of Social Information: Stock Market Listed Companies (2007). Accounting and Auditing Assessments Journal, 15, 55-70.

[18] Kashanipoor, M., Rahmani, A. and Parchini (2009) The Relationship between Voluntary Disclosure and Non-Executive Directors. Accounting and Auditing Assessments Journal, 16, 85-100.

[19] Francis, J., Nanda, D. and Olsson, P. (2008) Voluntary Disclosure, Earnings Quality, and Cost of Capital. Journal of Accounting Research, 46, 53-99.

[20] O’Dwyer, B. (2003) Conceptions of Corporate Social Responsibility: The Nature of Managerial Capture. Accounting, Auditing \& Accountability Journal, 16, 523-557. http://dx.doi.org/10.1108/09513570310492290

[21] Yazdi, H.K., Hemmati, K. and Bayat, A. (2012) The Assessment of Social Reporting on Behalf of Accepted Corporations Listed in Tehran Stock Exchange. Business Intelligence Journal, 5, 214-223.

[22] Watts, R.L. and Zimmerman, J.L. (1978) Towards a Positive Theory of the Determination of Accounting Standards. The Accounting Review, 53, 112-134.

[23] Jensen, M.C. and Meckling, W.H. (1976) Theory of the Firm: Managerial Behavior, Agency Costs and Ownership Structure. Journal of Financial Economics, 3, 305-360. http://dx.doi.org/10.1016/0304-405X(76)90026-X

[24] Watson, A., Shrives, P. and Marston, C. (2002) Voluntary Disclosure of Accounting Ratios in the UK. British Accounting Review, 34, 289-313. http://dx.doi.org/10.1006/bare.2002.0213

[25] Choi, F.D.S. (1973) Financial Disclosure and Entry to the European Capital Market. Journal of Accounting Research, 11, 159-175. http://dx.doi.org/10.2307/2490187

[26] Weisbach, M. (1988) Outside Directors and CEO Turnover. Journal of Financial Economics, 20, 431-461. http://dx.doi.org/10.1016/0304-405X(88)90053-0

[27] Wolk, H.I., Francis, J.R. and Tearney, M.G., Eds. (1992) Accounting Theory: A Conceptual and Institutional Approach. South Western Publishing, Mason.

[28] Lev, B. and Penman, S.H. (1990) Voluntary Forecast Disclosure, Non Disclosure and Stock Prices. Journal of Accounting Research, 28, 49-76. http://dx.doi.org/10.2307/2491217 
[29] Lang, M. and Lundholm, R. (1993) Cross-Sectional Determinants of Analyst Ratings of Corporate Disclosures. Journal of Accounting Research, 31, 246-271. http://dx.doi.org/10.2307/2491273

[30] Hassan, O. and Marston, C. (2010) Disclosure Measurement in the Empirical Accounting Literature: A Review Article. Working Paper No. 10-18, Economics and Finance Working Paper Series, Brunel University, London. http://dx.doi.org/10.2139/ssrn.1640598

[31] Alattar, J.M. and Al-Khater, K. (2007) An Empirical Investigation of Users' Views on Corporate Annual Reports in Qatar. International Journal of Commerce and Management, 17, 312-325. http://dx.doi.org/10.1108/10569210710844381

[32] Berger, P. and Hann, R. (2003) Segment Disclosures, Proprietary Costs, and the Market for Corporate Control. Working Paper, University of Chicago and University of Southern California.

[33] Hassan, O. and Marston, C. (2010) Disclosure Measurement in the Empirical Accounting Literature: A Review Article. Working Paper No. 10-18, Economics and Finance Working Paper Series, Brunel University, London. http://dx.doi.org/10.2139/ssrn.1640598

[34] Botosan, C.A. (2006) Disclosure and the Cost of Capital: What Do We Know? Accounting and Business Research, 36, 31-40. http://dx.doi.org/10.1080/00014788.2006.9730042

[35] Nagar, V., Nanda, D. and Wysocki, P. (2003) Discretionary Disclosure and Stock-Based Incentives. Journal of Accounting \& Economics, 34, 283-309. http://dx.doi.org/10.1016/S0165-4101(02)00075-7

[36] Akhtaruddin, M. (2005) Corporate Mandatory Disclosure Practices in Bangladesh. The International Journal of Accounting, 40, 399-422. http://dx.doi.org/10.1016/j.intacc.2005.09.007

[37] Camfferman, K. and Cooke, T.E. (2002) An Analysis of Disclosure in the Annual Reports of UK and Dutch Companies. Journal of International Accounting Research, 1, 3-30. http://dx.doi.org/10.2308/jiar.2002.1.1.3

[38] Healy, P. and Palepu. K. (2001) Information Asymmetry, Corporate Disclosure, and the Capital Markets: A Review of the Empirical Disclosure Literature. Journal of Accounting \& Economics, 31, 405-440. http://dx.doi.org/10.1016/S0165-4101(01)00018-0

[39] Campbell, D., Shrives, P. and Saager, H.B. (2001) Voluntary Disclosure of Mission Statements in Corporate Annual Reports: Signaling What and to Whom? Business and Society Review, 106, 65-87. http://dx.doi.org/10.1111/0045-3609.00102

[40] Graham, J.R., Harvey, C.R. and Rajgopal, S. (2005) The Economic Implications of Corporate Financial Reporting. Journal of Accounting and Economics, 40, 3-73. http://dx.doi.org/10.1016/j.jacceco.2005.01.002

[41] Griffin, C.H. and Williams, T.H. (1960) Measuring Adequate Disclosure. Journal of Accountancy, 109, 43-48.

[42] Lang, M. and Lundholm, R. (1996) Corporate Disclosure Policy and Analysts Behaviour. The Accounting Review, 71, 467-492.

[43] Al-Razeen, A. and Karbhari, Y. (2004) Interaction between Compulsory and Voluntary Disclosure in Saudi Arabian Corporate Annual Reports. Managerial Auditing Journal, 19, 351-360. http://dx.doi.org/10.1108/02686900410524364

[44] Alsaeed, K. (2006) The Association between Firm-Specific Characteristics and Disclosure: The Case of Saudi Arabia. Managerial Auditing Journal, 21, 476-496. http://dx.doi.org/10.1108/02686900610667256

[45] Lightstone, K. and Driscoll, C. (2008) Disclosing Elements of Disclosure: A Test of Legitimacy Theory and Company Ethics. Canadian Journal of Administrative Sciences, 25, 7-21. http://dx.doi.org/10.1002/cjas.50

[46] Zairi, M. and Letza, S. (1994) Corporate Reporting. Management Decision, 32, 30-40. http://dx.doi.org/10.1108/00251749410054792

[47] Gray, R., Owen, D. and Adams, C., Eds. (1996) Accounting and Accountability: Changes and Challenges in Corporate Social and Environmental Reporting. Prentice-Hall, London.

[48] Chau, G. and Gray, S.J. (2010) Family Ownership, Board Independence and Voluntary Disclosure: Evidence from Hong Kong. Journal of International Accounting, Auditing and Taxation, 19, 93-109. http://dx.doi.org/10.1016/j.intaccaudtax.2010.07.002

[49] Catasús, B. (2008) In Search of Accounting Absence. Critical Perspectives on Accounting, 19, 1004-1009. http://dx.doi.org/10.1016/j.cpa.2007.02.002

[50] Owusu-Ansah, S. (1998) The Impact of Corporate Attributes on the Extent of Mandatory Disclosure and Reporting by Listed Companies in Zimbabwe. The International Journal of Accounting, 33, 605-629. http://dx.doi.org/10.1016/S0020-7063(98)90015-2

[51] Nahandi, Y.B. (2009) Developing and Presenting a Model to Determine and Assess the Contributing Factors on Financial Reporting Quality in Iran. Ph.D. Dissertation in Accounting, Faculty of Management and Economics, Science and Research Branch, Islamic Azad University, Tehran. 